\title{
ВИВЧЕННЯ ПОТРЕБ ПАЦІЄНТІВ У ПРОЦЕСІ НАДАННЯ ПАЛІАТИВНОЇ ДОПОМОГИ НА АМБУЛАТОРНОМУ РІВНI
}

\author{
${ }^{1}$ ввано-Франківський національний медичний університет, м. Івано-Франківськ, Україна \\ ${ }^{2}$ Національна медична академія післядипломної освіти імені П. Л. Шупика, м. Київ, Україна
}

\begin{abstract}
Мета: вивчити потреби пацієнтів, яким надають паліативну допомогу на амбулаторному рівні.
Матеріали і методи. Опитано 219 пацієнтів, яким надавали паліативну допомогу вдома, мешканців м. Ужгорода. Використано соціологічний та медико-статистичний методи.

Результати. Встановлено, що тотальна більшість $(97,1$ \%) пацієнтів у термінальній стадії тяжкої хвороби хоче, щоб їм надавали паліативну допомогу за місцем проживання і бути поінформована про свій діагноз та прогноз $(98,2 \%)$.

Виявлено, що сімейні лікарі у процесі взаємодії з паліативними пацієнтами допускають такі окремі недоліки, як: не проведення оцінки ступеня болю (12,3\%), відсутність обговорення з пацієнтами фрорми приймання знеболювальних $(15,4 \%)$, неповна корекція болю $(22,1 \%)$ та інших супутніх симптомів (26,8 \%), недостатнє консультування родичів $(41,2 \%)$.

Показано, що паліативні пацієнти мають значну потребу в психологічній (78,4 \%), духовній (79,6 \%) та соціальній (78,5 \%) підтримці. При цьому на тлі загально низького рівня їх матеріального благополуччя (64,3 \%) основними доглядальниками $(83,1 \%)$ та джерелом психологічної підтримки $(71,0 \%) €$ родичі пацієнтів при недостатній участі психологів, соціальних працівників та священнослужителів.

Висновки. Для забезпечення медичних, інформаційних, психологічних, соціальних та духовних потреб паліативних хворих необхідно удосконалювати підготовку сімейних лікарів із питань паліативної допомоги та налагодити координацію їхніх дій з мобільними паліативними та соціальними службами.
\end{abstract}

КЛЮчОВІ СЛОВА: сімейні лікарі; паліативна допомога.

Відповідно до базових принципів паліативної допомоги (ПД) пацієнти мають право її отримувати в місці свого безпосереднього перебування: вдома, на амбулаторному рівні чи в стаціонарних закладах охорони здоров'я. За рекомендаціями Європейської асоціації паліативної допомоги: «команди паліативної допомоги співпрацюють з професійними та нефрормальними піклувальниками у кожному із цих середовищ для забезпечення координації, комунікації та безперервності ПД у всіх місцях - інституційних закладах та вдома [15]. Питання організації ПД набуває актуальності при формуванні політики надання медичної допомоги на амбулаторному рівні, зокрема вдома. У 2014 р. Україна спільно зі світовою медичною спільнотою у межах 67-ї сесії Всесвітньої асамблеї здоров'я ВОО3 (Женева, 2014) доєдналася до окремої Резолюції з питань ПД. У Резолюції «Посилення паліативної допомоги як складової комплексного догляду протягом усього життєвого шляху», зокрема, наголошувалося на необхідності «впровадження послуги з паліативної допомоги в умовах постійної допомоги на всіх рівнях, з акцентом на первинну медичну допомогу» [19]. На законодавчому рівні в Україні закріплені основні принципи ПД: доступність, висока якість,

(с О. 3. Децик, О. П. Брацюнь, 2020 безперервність, наступність та основні її складові: запобігання та лікування хронічного больового синдрому, симптоматична терапія, догляд, психологічна і духовна підтримка пацієнта та його родини. Визначено основні види паліативної допомоги: загальна, яку надають вдома та в закладах охорони здоров'я, які надають первинну медичну допомогу (ПМД), та спеціалізована, яку надає мультидисциплінарна команда, до складу якої входять медичні працівники, які отримали спеціальну підготовку з надання ПД, психологи, соціальні працівники, спеціалісти 3 надання духовної підтримки та інші фахівці за потребою, волонтери та найближчі родичі $[3,7,8]$.

У рамках проведеного у 2018-2019рр. в Україні першого етапу ресоори охорони здоров'я при наданні ПМД законодавчо урегульовано надання послуг ПД у місцях перебування пацієнтів. Зокрема, у функції сімейних лікарів включено регулярну оцінку стану тяжкохворого пацієнта та його потреб; оцінку ступеня болю та лікування больового синдрому; призначення наркотичних засобів та психотропних речовин відповідно до законодавства, включаючи офрормлення рецептів для лікування больового синдрому; призначення лікування для подолання супутніх симптомів (закрепи, нудота, задуха тощо); 
консультування та навчання осіб, які здійснюють догляд за пацієнтом; координацію із забезпечення медичних, психологічних тощо потреб пацієнта, направлення пацієнтів відповідно до медичних показань для надання їм ПД в обсязі, що виходить за межі ПМД [4, 9].

Разом із тим, доводиться констатувати, що, поряд зі значним поступом у сорері розвитку ПД, комплексне забезпечення проблем пацієнтів при наданні ПмД залишається недостатньо вирішеним.

Мета роботи: вивчити потреби пацієнтів, яким надають паліативну допомогу на амбулаторному рівні.

Матеріали і методи. На базі закладів охорони здоров'я м. Ужгорода провели медико-соціальне дослідження за власною програмою пацієнтів, яким надавали ПД. Опитувальник складався 3 соціально-демографрічних характеристик щодо віку, статі, місця проживання, цивільного та соціального стану, рівня освіти і доходів, приналежності до релігійних спільнот та 21 запитання щодо медичних і немедичних потреб пацієнтів та особливостей догляду, який вони отримували. Більшість запитань опитувальника були закритими і передбачали відповіді «Так» або «Ні», або вибір одного із запропонованих варіантів. Відкритими були запитання щодо віку та характеру труднощів при отриманні рецепта на лікарські засоби для знеболювання.

Перед початком дослідження для сімейних лікарів Ужгородського міського центру первинної медико-санітарної допомоги (ЦПМСД) був проведений тренінг щодо відбору пацієнтів для дослідження. Для випускників медичного фракультету ДВНЗ «Ужгородський національний університет», які проходили інтернатуру на базі Ужгородського міського ЦПМСД та які безпосередньо здійснювали опитування пацієнтів як волонтери, проведено навчання з етичних питань дослідження та практичних питань анкетування. Час опитування становив приблизно 15 хв.

Дослідження проводили протягом 20182019 рр. Для участі в дослідженні залучено пацієнтів, яким надавали ПД у місці їх проживання (перебування) 3 боку сімейних лікарів м. Ужгорода Закарпатської області. Загальна кількість респондентів склала 219 осіб, 3 них 46,8 \% [95 \% ДІ 40,34-53,41] чоловіків і 53,2 \% [95 \% Ді 46,5959,66] жінок віком від 27 до 93 років, $95 \%$ опитаних мешкали в місті. Середній вік пацієнтів становив 66,24 року (12,93 року). Серед опитаних 83,2 \% хворіли на онкологічні захворювання IV стадії, 16,8 \% - на хронічні прогресуючі захворювання в термінальній стадії.

Дослідження проводили 3 використанням вибіркового методу (формування досліджуваної групи шляхом випадкового відбору) та методу анкетування (опитування пацієнтів за допомогою анкет). При аналізі даних використовували методи описової статистики (для кількісних параметрів - n, середнє арифметичне, медіана, стандартне відхилення, мінімум та максимум, а для категоріальних даних - кількість на частку у відсотках) та методи інтервального оцінювання (були побудовані 95 \% довірчі інтервали для часток) [10]. Статистичний аналіз даних проводили за допомогою вбудованих засобів статистичного аналізу електронних таблиць Microsoft Excel і пакета прикладних програм SPSS 13.0.

Результати дослідження та їх обговорення. Встановлено, що серед опитаних пацієнтів тільки поодинокі - 6,1 \% [95 \% ДІ 3,48-10,24] оцінювали свої доходи як високі та близько третини - 29,6 \% [95 \% ДІ 23,74-36,33] як середні. Решта - а це дві третини респондентів - 64,3 \% [95 \% ДІ 57,4570,65] відносили себе до малозабезпечених осіб.

Очевидно, ця обставина могла вплинути на те, що основними доглядальниками для більшості пацієнтів є їхні родичі - 83,1 \% [95 \% ДІ 77,39-87,58], і тільки в 11,6 \% [95 \% ДІ 7,92-16,67] зазначену послугу виконують залучені доглядальники. При цьому роль інших можливих надавачів таких послуг взагалі мізерна: патронажні сестри беруть участь в догляді лише 1,0 \% [95 \% ДІ 0,27-3,45] респондентів, працівники соціальних служб задіяні у 2,9 \% [95 \% ДІ 1,34-6,18] випадків, представники релігійних спільнот у 1,4\% [95 \% ДІ 0,49-4,17]. Встановлене містить загрози несприятливих наслідків. Адже, на думку більшості дослідників, кожен десятий доглядальник страждає від емоційного вигорання, що може призводити до проблем зі здоров'ям, емоційних розладів та посилення фрінансових труднощів. У зв'язку з цим, доглядальники потребують інфрормаційної, психологічної та практичної підтримки [18], у тому числі відповідного оволодіння навичками із догляду за тяжкохворими [2]. Однак у дослідженні встановлено, що тільки 58,8 \% [95 \% ДІ 52,13-65,15] доглядальників отримали від сімейних лікарів консультації щодо того, як оптимально організувати догляд за пацієнтом, а 41,2 \% [95 \% ДІ 34,85-47,87] - не отримали.

Виявлено, що тотальна більшість респондентів (97,1 \% [95 \% ДІ 93,85-98,67]) висловила бажання, щоб їм надавали медичну допомогу, перебуваючи у місці власного проживання. Це співпадає із загальносвітовими тенденціями. Адже, згідно 3 дослідженнями, переважна кількість пацієнтів з обмеженим прогнозом життя вказує на те, що хоче померти вдома, а отже, і ПД доцільно надавати саме вдома $[12,14]$.

Встановлено, що інформацію про діагноз та можливий прогноз захворювання опитані отримують від своїх сімейних лікарів (65,0% [95 \% 
ДІ 58,42-71,01]), рідше - від лікарів-спеціалістів (24,0 \% [95 \% ДІ 18,77-30,06]) і спорадично - від родичів (4,1 \% [95 \% ДІ 2,20-7,69]). Маловагомим виявився відсоток пацієнтів, не поінформованих щодо свого діагнозу та можливого прогнозу, 5,1 \% [95 \% ДІ 2,85-8,85], і одиниці - 1,8 \% [95 \% ДІ 0,72-4,64] серед опитаних взагалі відмовилися отримувати зазначену інорормацію.

Результати нашого дослідження корелюють 3 результатами інших подібних досліджень, які показали, що зазвичай паліативні пацієнти бажають знати, чи є в них небезпечна хвороба [17]. Тому сімейні лікарі як основні провайдери ПД повинні мати навички ефективних комунікацій 3 пацієнтами та доглядальниками, інорормувати їх про наявні варіанти управління симптомами, залучати до прийняття рішень, підтримувати психологічно та, за потреби, залучати інших спеціалістів [20].

У цьому плані наше дослідження показало, що сімейні лікарі в цілому непогано взаємодіяли із пацієнтами, більшість з яких визначала ступінь больового синдрому - 87,7 \% [95 \% ДІ 82,73-91,43] та обговорювала форму приймання лікарських засобів для усунення болю та інших симптомів хвороби - 84,6 \% [95 \% ДІ 79,09-88,89]. Разом із тим, все-таки 15,4 \% [95\% ДІ 11,11-20,91] опитаних тяжкохворих пацієнтів фракт такого обговорення заперечили, а в 12,3 \% [95 \% ДІ 8,57-17,27] респондентів сімейні лікарі не оцінили ступінь болю, попри те, що усунення або полегшення несприятливих симптомів хвороби є одним 3 основних завдань ПД. Біль - це один із найбільш яскраво виражених негативних симптомів, що найсуттєвіше впливає на якість життя пацієнтів, спричиняючи стрес, фрізичні та моральні страждання [16]. Тому оцінка ступеня болю та підбір лікарських засобів, здатних максимально полегшити або усунути дискомфорт, є безпосереднім завданням лікарів, які надають Пд.

Встановлено, що в більшості опитаних (77,9\% [95 \% ДІ 71,77- 82,99]) призначені ліки знімали біль повністю, тобто сімейні лікарі досить успішно підбирають препарати для усунення больового синдрому. Це дещо суперечить даним про те, що в Україні все ще існує досить серйозна проблема 3 доступом до ефективного знеболювання, а приймання опіоїдних анальгетиків $є$ недостатнім і не покриває потреби населення $[11,13]$.

Разом із тим, практично у кожного четвертого пацієнта (22,0 \% [95 \% ДІ 17,01-28,23]) знеболювання, призначене сімейним лікарем, не досягало позитивного ефректу.

Слід акцентувати, що, крім больового синдрому, майже 80,0 \% (79,1 \% [95 \% ДІ 73,24-83,94]) опитаних мали й інші супутні симптоми, а саме: закрепи, нудоту, задуху, порушений сон. При цьому 89,1 \% [95 \% ДІ 83,81-92,85] таких респон- дентів зазначали, що сімейні лікарі призначали лікування вказаних симптомів, однак тільки у 73,2 \% [95 \% ДІ 66,38-79,11] випадків це привело до полегшення, а у решти - ні.

Аналіз даних щодо немедичних проблем паліативних пацієнтів показав, що більшість 3 них стикнулася 3 проблемами психоемоційного, духовного та соціального характеру. Так, 78,4 \% [95 \% ДІ 72,51-83,38] опитаних потребували психологічної допомоги. Однак лише у 75,1 \% [95 \% ДІ 68,96-80,40] таких випадків сімейні лікарі пропонували пацієнтам звернутися за допомогою до профресійного психолога, а в 24,9 \% [95 \% ДІ 19,60-31,04] - зазначеної пропозиції не давали. Значною мірою це пов'язано із нерозвиненістю відповідних інституцій в Україні. Зокрема посади психолога в закладах охорони здоров'я, що надають ПМД, немає. Все це ускладнює можливість пацієнтів отримати професійну психологічну підтримку. Як ілюстрація - опитані тяжкохворі пацієнти визнали, що основним джерелом психологічної підтримки для них $є$ родичі (71,0 \% [95 \% ДІ 62,71-78,08]) і меншою мірою - друзі (14,5 \% [95 \% ДІ 9,49-21,54]) чи релігійна спільнота (9,9 \% [95 \% ДІ 5,89-16,24]). При цьому незначна частка респондентів (4,6 \% [95 \% ДІ 2,12-9,63]) вказала на поєднання декількох джерел психологічної підтримки.

Більшість опитаних (79,6 \% [95 \% ДІ 73,76$84,46])$ визнала, що має потребу й у духовній підтримці. Як ресурси, якими послуговувалися пацієнти для її задоволення, респонденти називали молитву $(40,3$ \% [95 \% ДІ 32,38-48,76]) і спілкування (44,0\% [95 \% ДІ 35,91-52,49]), а значно рідше природу (9,0 \% [95 \% ДІ 5,20-15,00]) та мистецтво (2,2 \% [95 \% ДІ 0,76-6,38]). Поєднання декількох із перелічених ресурсів притаманне було тільки у 4,5 \% [95 \% ДІ 2,07-9,42] респондентів. На жаль, в умовах чинного законодавства України залучення священнослужителів для надання духовної опіки пацієнтів вдома має епізодичний характер, а процес створення системи надання духовного супроводу при отриманні медичної допомоги перебуває на стадії законодавчого урегулювання [5].

За результатами дослідження також встановлено, що 78,5 \% [95 \% ДІ 72,63-83,46] опитаних у час тяжкої недуги страждали від проблем соціального характеру. Проте для задоволення соціальних потреб пацієнтів при наданні ПМД існують перепони, які зумовлені відсутністю алгоритму взаємодії між медичними працівниками та працівниками соціальної сорери, попри наявність законодавчих норм щодо надання послуги «соціальна послуга - паліативний догляд» [6].

Міжнародний та вітчизняний досвід свідчить, що зазначені проблеми пацієнтів успішно вирішуються при залученні для надання ПД мобільних паліативних бригад, які застосовують у своїй 
роботі мультидисциплінарний підхід [1]. Протягом останніх років у кількох регіонах України почали фрункціонувати мобільні паліативні бригади, які надають ПД для дорослих пацієнтів. Проте, щоб забезпечити потребу пацієнтів у ПД на амбулаторному рівні, кількість мобільних паліативних бригад необхідно збільшувати та їхній персонал повинен отримати спеціальні знання з питань надання ПД.

\section{Висновки}

Встановлено, що тотальна більшість (97,1%) пацієнтів у термінальній стадії тяжкої хвороби хоче, щоб їм надавали паліативну допомогу за місцем проживання і бути поінформована про свій діагноз та прогноз (98,2 \%).

Виявлено, що сімейні лікарі у процесі взаємодії 3 паліативними пацієнтами допускають такі окремі недоліки, як: не проведення оцінки ступеня болю (12,3\%), відсутність обговорення 3 пацієнтами фрорми приймання знеболювальних $(15,4$ \%), неповна корекція болю (22,1 \%) та інших супутніх симптомів (26,8 \%), недостатнє консультування родичів (41,2\%).

Показано, що паліативні пацієнти мають значну потребу в психологічній (78,4\%), духовній (79,6 \%) та соціальній (78,5 \%) підтримці. При цьому на тлі загально низького рівня їх матеріального благополуччя (64,3 \%) основними доглядальниками (83,1 \%) та джерелом психологічної підтримки (71,0 \%) є родичі пацієнтів при недостатній участі психологів, соціальних працівників та священнослужителів.

Для забезпечення медичних, інформаційних, психологічних, соціальних та духовних потреб паліативних хворих необхідно удосконалювати підготовку сімейних лікарів із питань паліативної допомоги та налагодити координацію їхніх дій 3 мобільними паліативними та соціальними службами.

Перспективи подальших досліджень полягатимуть у розробці функціонально-організаційної моделі удосконалення надання паліативної допомоги на рівні пМД.

\section{Список літератури}

1. Гойда Н. Г. Соціально-медичні аспекти розвитку паліативної та хоспісної допомоги в Україні в умовах ресрормування системи охорони здоров'я / Н. Г. Гойда, Ю. І. Губський, А. В. Царенко // Реабілітація та паліативна медицина. 2015. - № 2. - С. 23-30.

2. Децик О. З. Паліативна допомога: проблеми сімей інкурабельних хворих / О. З. Децик, Ж. М. Золотарьова // Реабілітація та паліативна медицина. - 2015. - № 1. - С. 55-59.

3. Основи законодавства України про охорону здоров'я : Закон України від 19 листопада 1992 року № 2801-XII [Електронний ресурс]. - Режим доступу : https://zakon.rada.gov.ua/laws/show/2801-12.

4. Про державні фрінансові гарантії медичного обслуговування населення : Закон України від 19 жовтня 2017 року № 2168-VIII (редакція від 20.03.2020р.) [Електронний ресурс]. - Режим доступу : https://zakon.rada.gov.ua/laws/ show/2168-19.

5. Законодавчі аспекти запровадження душпастирської опіки в сфері охорони здоров'я / С. Г. Убогов, о. Андрій Нагірняк, о. Сергій Дмитрієв, О. П. Брацюнь // Інтегративна антропологія. - 2016. - № 2 (28). - С. 33-37.

6. Про затвердження Порядку взаємодії суб'єктів при наданні соціальної послуги паліативного догляду вдома невиліковно хворим : наказ Міністерства соціальної політики України та МОЗ України від 23.05.2014 р. № $317 / 353$ [Електронний ресурс]. - Режим доступу : http://zakon4.rada.gov.ua/laws/show/z0625-14.

7. Про затвердження Положення про центр первинної медичної (медико-санітарної) допомоги та положень про його підрозділи : наказ МОЗ України від 29.07.2016 р. № 801 [Електронний ресурс]. - Режим доступу : https://zakon. rada.gov.ua/laws/show/z1167-16.

8. Про організацію паліативної допомоги в Україні : наказ мО3 України від 21.01.2013 р. № 41 [Електронний ресурс]. - Режим доступу : https://zakon.rada.gov.ua/laws/show/z0229-13.

9. Про затвердження Порядку надання первинної медичної допомоги : наказ МОЗ України від 19.03.2018 р. № 504 [Електронний ресурс]. - Режим доступу : https://zakon.rada.gov.ua/laws/show/z0348-18.

10. Петри А. Наглядная статистика в медицине : учебное пособие / А. Петри, К. Сэбин ; пер. с англ. под ред. В. П. Леонова. - М. : ГЭОТАР-МЕД, 2003. - 144 с. : ил. - (Серия «Экзамен на отлично»).

11. Ткаченко О. В. Аналітичний звіт. Споживання опіоїдних анальгетиків в Україні. 2011-2016 роки / О. В. Ткаченко, Н. О. Дацюк // Міжнародний фонд Відродження, Інститут аналітики та адвокації, 2019.

12. Congruence between preferred and actual place of death for those in receipt of home-based palliative care / J. Cai,

L. Zhang, D. Guerriere [et al.] // J. Palliat. Med. Published online April 15, 2020. DOI:10.1089/jpm.2019.0582

13. EAPC Atlas of Palliative Care in Europe, 2019/ Arias-Casais, Natalia \& Garralda, Eduardo \& Rhee, at al.

14. End-of-life care: Where do cancer patients want to die? A systematic review / J. Nilsson, C. Blomberg, G. Holgersson [et al.] // Asia Pac. J. Clin. Oncol. - 2017. - Vol. 13 (6). - P. 356-364. DOI:10.1111/ajco.12678

15. National Consensus Project for Quality Palliative Care. Clinical Practice Guidelines for Quality Palliative Care, 2004 16. Strömgren A. S. Pain characteristics and treatment outcome for advanced cancer patients during the first week of specialized palliative care / A. S. Strömgren // Journal of Pain and Symptom Management. - 2004. - Vol. 27 (2). P. 104-113.

17. Patients' preferences for involvement in treatment decision making in Japan / M. Sekimoto, A. Asai, M. Ohnishi [et al.] // BMC Fam. Pract. - 2004. - Vol. 5 (1). - P.1. PMID: 15053839 
18. Profiles of family caregivers of patients at the end of life at home: a Q-methodological study into family caregiver' support needs / F. M. Bijnsdorp, H. R. W. Pasman, C. R. L. Boot [et al.] // BMC Palliat Care. - 2020. - Vol. 19. DOI:10.1186/ s12904-020-00560-x. Access mode : https://www.ncbi.nlm.nih.gov/pmc/articles/PMC7175554/\#CR1

19. Strengthening of palliative care as a component of comprehensive care throughout the life course Access mode : https://apps.who.int/gb/ebwha/pdf_files/WHA67/A67_R19-en.pdf

20. The required competencies of physicians within palliative care from the perspectives of multi-professional expert groups: a qualitative study / H.-L. Melender, M. Hökkä, T. Saarto [et al.] // BMC Palliat Care. - 2020. - Vol. 19 (1). - P. 65. DOI:10.1186/s12904-020-00566-5. Access mode : https://bmcpalliatcare.biomedcentral.com/articles/10.1186/s12904020-00566-5

\section{References}

1. Hoyda, N.G., Hubsky, Y.I., \& Tsarenko, A.V. (2015). Sotsialno-medychni aspekty rozvytku paliatyvnoi ta khospisnoi dopomohy $v$ Ukraini $v$ umovakh reformuvannia systemy okhorony zdorovia [Socio-medical aspects of the development of palliative and hospice care in Ukraine in terms of reforming the health care system]. Reabilitatsiia ta paliatyvna medytsynaRehabilitation and Palliative Medicine, 2, 23-30 [in Ukrainian].

2. Detsyk O.Z., \& Zolotareva, J.M. (2015). Paliatyvna dopomoha: problemy simei inkurabelnykh khvorykh [Palliative care: problems of families of incurable patients]. Reabilitatsiia ta paliatyvna medytsyna - Rehabilitation and Palliative Medicine, 1, 55-59. Retrieved from: http://nbuv/gov/ua/UJRN/rpm_2015_1_14 [in Ukrainian].

3. Zakon Ukrainy "Osnovy zakonodavstva Ukrainy pro okhoronu zdorovia" [Law of Ukraine "Fundamentals of the legislation of Ukraine on health care"]. zakon.rada.gov.ua Retrieved from: https://zakon.rada.gov.ua/laws/show/2801-12 [in Ukrainian]. 4. (2020). Zakon Ukrainy "Pro derzhavni finansovi harantii medychnoho obsluhovuvannia naselennia" (redaktsiia vid 20.03 2020) [Law of Ukraine "On state financial guarantees of medical care" (version of 20.03 2020)]. zakon.rada.gov.ua Retrieved from: https://zakon.rada.gov.ua/laws/show/2168-19] [in Ukrainian].

5. Ubohov, S.H., Pr. Andrii Nahirnyak, Pr. Serhii Dmitriev, \& Bratsyun, O.P. (2016). Zakonodavchi aspekty zaprovadzhennia dushpastyrskoi opiky $v$ sferi okhorony zdorovia [Legislative aspects of the introduction of pastoral care in the field of health]. Intehratyvna antropolohiia - Integrative Anthropology, 2 (28), 33-37 [in Ukrainian].

6. (2014). Nakaz Ministerstva sotsialnoi polityky Ukrainy ta MOZ Ukrainy vid 23.05.2014 № 317/353 Pro zatverdzhennia Poriadku vzaiemodii subiektiv pry nadanni sotsialnoi posluhy paliatyvnoho dohliadu vdoma nevylikovno khvorym" [Order of the Ministry of Social Policy of Ukraine and the Ministry of Health of Ukraine dated 23.05.2014 No. 317/353 On approval of the Procedure for interaction of subjects in providing social services of palliative care at home to terminally ill patients"]. zakon4.rada.gov.ua Retrieved from: http://zakon4.rada.gov.ua/laws/show/z0625-14 [in Ukrainian].

7. (2016). Nakaz MOZ Ukrainy № 801 vid 29.07.2016 [Order of the Ministry of Health of Ukraine No. 801 dated July 29 , 2016]. zakon.rada.gov.ua Retrieved from: https://zakon.rada.gov.ua/laws/show/z1167-16 [in Ukrainian].

8. (2013). Nakaz MOZ Ukrayiny №41 vid 21.01.2013 "Pro orhanizatsiiu paliatyvnoi dopomohy v Ukraini" [Order of the Ministry of Health of Ukraine No. 41 of 21.01.2013 "On the organization of palliative care in Ukraine"]. zakon.rada.gov.ua Retrieved from: https://zakon.rada.gov.ua/laws/show/z0229-13 [in Ukrainian].

9. (2018). Nakaz MOZ Ukrainy vid 19.03.2018 r. № 504 "Pro zatverdzhennia poriadku nadannia pervynnoi medychnoi dopomohy" [Order of the Ministry of Health of Ukraine dated March 19, 2018 № 504 "On approval of the procedure for providing primary care"]. zakon.rada.gov.ua Retrieved from: https://zakon.rada.gov.ua/laws/show/z0348-18 [in Ukrainian]. 10. Petri, A., \& Sebin, K. (2003). Naglyadnaya statistika $v$ meditsine [Visual statistics in medicine]. (V.P. Leonova Trans.) Moscow: GEOTAR-MED [in Russian].

11. Tkachenko, O.V., \& Datsyuk, N.O. (2019). Analitychnyy zvit. Spozhyvannia opioidnykh analhetykiv v Ukraini. $2011-2016$ roky [Analytical report. Consumption of opioid analgesics in Ukraine. 2011-2016]. International Renaissance Foundation, Institute of Analytics and Advocacy [in Ukrainian].

12. Cai, J., Zhang, L., Guerriere, D., \& Coyte, P.C. (2020). Congruence between preferred and actual place of death for those in receipt of home-based palliative care. J. Palliat. Med., Published online April 15. DOI:10.1089/jpm.2019.0582

13. Arias-Casais, Natalia \& Garralda, Eduardo \& Rhee, John \& De Lima, Liliana \& Pons Izquierdo, Juan \& Clark, David \& Hasselaar, Jeroen \& Mosoiu, Daniela \& Ling, Julie \& Centeno, Carlos. (2019). EAPC Atlas of Palliative Care in Europe 2019. 14. Nilsson, J., Blomberg, C., Holgersson, G., Carlsson, T., Bergqvist, M., \& Bergström, S. (2017). End-of-life care: Where do cancer patients want to die? A systematic review. Asia Pac. J. Clin. Oncol., 13(6), 356-364. DOI:10.1111/ajco.12678

15. (2004). National Consensus Project for Quality Palliative Care. Clinical Practice Guidelines for Quality Palliative Care. 16. Strömgren, A.S. (2004). Pain characteristics and treatment outcome for advanced cancer patients during the first week of specialized palliative care. Journal of Pain and Symptom Management. 27 (2), 104-113.

17. Sekimoto, M., Asai, A., \& Ohnishi, M. (2004). Patients' preferences for involvement in treatment decision making in Japan. BMC Fam. Pract., 5(1), 1. PMID: 15053839

18. Bijnsdorp, F.M., Pasman, H.R.W., Boot, C.R.L., van Hooft S.M., van Staa, A., \& Francke, A.L. (2020). Profiles of family caregivers of patients at the end of life at home: a Q-methodological study into family caregiver' support needs. BMC Palliat. Care, 19. DOI:10.1186/s12904-020-00560-x, Retrieved from: https://www.ncbi.nlm.nih.gov/pmc/articles/ PMC7175554/\#CR1

19. Strengthening of palliative care as a component of comprehensive care throughout the life course. Retrieved from: https://apps.who.int/gb/ebwha/pdf_files/WHA67/A67_R19-en.pdf

20. Melender, H-L., Hökkä, M., Saarto, T., \& Lehto, J.T. (2020). The required competencies of physicians within palliative care from the perspectives of multi-professional expert groups: a qualitative study. BMC Palliat Care., 19 (1), 65. DOI:10.1186/ s12904-020-00566-5 Retrieved from: https://bmcpalliatcare.biomedcentral.com/articles/10.1186/s12904-020-00566-5 
STUDY OF PATIENTS' NEEDS IN THE PROCESS OF PALLIATIVE CARE AT THE OUTPATIENT BASIS

O. Z. Detsyk ${ }^{1}$, O. P. Bratsyun ${ }^{2}$

${ }^{1}$ Ivano-Frankivsk National Medical University, Ivano-Frankivsk, Ukraine

${ }^{2}$ P. Shupyk National Medical Academy of Postgraduate Education, Kyiv, Ukraine

Purpose: to examine the needs of patients receiving palliative care at the outpatient basis.

Materials and Methods. 219 patients who received palliative care at home, residents of Uzhhorod, were interviewed. Sociological and medical-statistical methods were used.

Results. It was found that the total majority (97.1\%) of patients in the terminal stage of serious illness want to receive palliative care at the place of residence and be informed about their diagnosis and prognosis (98.2\%).

It was found that family physicians in the process of interaction with palliative patients admit some shortcomings, such as: failure to assess the degree of pain (12.3\%), lack of discussion with patients about the form of analgesics (15.4\%), incomplete pain correction (22.1\%) and other concomitant symptoms (26.8\%), insufficient counseling of relatives (41.2\%).

It was shown that palliative patients have a significant need for psychological (78.4\%), spiritual (79.6 \%) and social (78.5\%) support. At the same time, against the background of the general low level of their material wellbeing $(64.3 \%)$, the main caregivers (83.1\%) and the source of psychological support $(71.0 \%)$ are relatives of patients with insufficient participation of psychologists, social workers and clergy.

Conclusion. To meet the medical, informational, psychological, social and spiritual needs of palliative care patients, it is necessary to improve the training of family physicians in palliative care and to establish coordination of their actions with mobile palliative and social services.

KEY WORDS: family doctors; palliative care.

Рукопис надійшов до редакції 27.01.2020 p.

Відомості про авторів:

Децик Орина Зенонівна - доктор медичних наук, професор, завідувач кафедри соціальної медицини та громадського здоров'я Івано-Франківського національного медичного університету; тел.: +38(050) 373-33-09, +38(096) 575-24-50.

Брацюнь Олександра Петрівна - асистент кафедри паліативної та хоспісної медицини Національної медичної академії післядипломної освіти імені П. Л. Шупика; тел.: +38(067) 440-88-34. 